Eastern Illinois University

The Keep

Faculty Research \& Creative Activity

Biological Sciences

January 2010

\title{
Relative allelopathic potential of invasive plant species in a young disturbed woodland
}

Nikki Pisula

Eastern Illinois University

Scott J. Meiners

Eastern Illinois University, sjmeiners@eiu.edu

Follow this and additional works at: http://thekeep.eiu.edu/bio_fac

Part of the Biology Commons, and the Plant Sciences Commons

\section{Recommended Citation}

Pisula, Nikki and Meiners, Scott J., "Relative allelopathic potential of invasive plant species in a young disturbed woodland" (2010). Faculty Research \& Creative Activity. 15.

http://thekeep.eiu.edu/bio_fac/15 


\section{The Journal of the}

\section{Torrey Botanical Society}

Relative allelopathic potential of invasive plant species in a young disturbed woodland ${ }^{1}$

Nikki L. Pisula ${ }^{2,3}$ and Scott J. Meiners

Department of Biological Sciences, Eastern Illinois University, Charleston, IL 61920 



\title{
Relative allelopathic potential of invasive plant species in a young disturbed woodland ${ }^{1}$
}

\author{
Nikki L. Pisula ${ }^{2,3}$ and Scott J. Meiners \\ Department of Biological Sciences, Eastern Illinois University, Charleston, IL 61920
}

\begin{abstract}
Pisula, N. L. And S. J. Meiners. (Department of Biological Sciences, Eastern Illinois University, Charleston, IL 61920). Relative allelopathic potential of invasive plant species in a young disturbed woodland. J. Torrey Bot. Soc. 137: 81-87. 2010-Invasive plant species are often more successful within introduced areas when compared to their natural ranges. Allelopathy has been suggested as a potential mechanism for this success because invasive plants frequently establish monocultures and may produce allelochemicals evolutionarily novel to the recipient community. However, species are typically tested in isolation making the relative strength of allelopathy difficult to assess. We conducted laboratory bioassays for 10 co-occurring non-native species to determine the relative strength of their allelopathic potential. These species represented a suite of successful invaders within a young forest and were from a variety of plant life forms: trees, lianas, shrubs, and herbs. We determined the germination responses of a target species to a gradient of leaf extract concentrations to assess relative allelopathic potential. The relative strength of germination inhibition was quantified by the slope $(\beta)$ of the germination response to plant extract concentration. Ailanthus altissima extract had the greatest inhibitory effect on target species germination out of all 10 species $(\beta=-0.55)$ while the other tree species, Acer platanoides extract, had small effects on germination $(\beta=-0.14)$. For lianas, Celastrus orbiculatus extract inhibited the target species $(\beta=-0.28)$ more than Lonicera japonica extract $(\beta=-0.06)$. All invasive shrub extracts had very small effects on seed germination ( $\beta$ value -0.03 to -0.19 ). Extracts of the two herbaceous species, Alliaria petiolata and Microstegium vimineum, had very large inhibitory effects $(\beta=-0.37$ and -0.38 , respectively). In this system, we screened a suite of invasive species for allelopathic potential and determined the relative strength of germination inhibition. Most species, particularly invasive shrubs, did not exhibit sufficient allelopathic potential to suggest allelopathy would occur in the field. Four species, Ailanthus altissima, Alliaria petiolata, C. orbiculatus, and $M$. vimineum all exhibited strong germination inhibition and warrant additional study in the field.
\end{abstract}

Key words: allelopathy, bioassay, comparative ecology, germination inhibition, invasive species.

Invasive plant species are responsible for disrupting ecosystems and are of concern to conservationists worldwide. Once an invader enters a recipient community, it has the potential to occupy large areas, posing numerous problems for native flora and fauna. Because of these problems, the determinants of species invasiveness and the invasibility of communities are vital for understanding the ecology of non-native species (Crawley 1987, Rejmánek 1999, Mack et al. 2000, Ehrenfeld et al. 2001, Byers et al. 2002, Huston 2004). Several mechanisms have been proposed to explain invasive plant species success within introduced areas compared to their natural ranges. Among these mechanisms, life-history characteristics, physiological properties, rapid

\footnotetext{
1 This work was supported by NSF DEB 0424605

2 We thank L. M. Ladwig for comments on previous drafts of this manuscript. We also thank $\mathbf{J}$. Lyerla-Kirkton for help with laboratory bioassays.

3 Author for correspondence. E-mail: nlpisula@ eiu.edu

Received for publication July 14, 2009, and in revised form December 18, 2009.
}

changes in genetics, and escape from natural enemies, may all contribute to the invasibility of non-natives (Rejmánek and Richardson 1995, Williamson 1996, Reichard and Hamilton 1997, Ehrenfeld et al. 2001). More recently, allelopathy has been suggested as a potentially important mechanism of plant invasion success, particularly when the invaders produce evolutionarily novel chemicals (Hierro and Callaway 2003, Inderjit et al. 2008).

Allelopathy has been broadly defined as the production of chemical compounds by one plant species that influence another plant species, mostly in a deleterious way (Newman 1983, Rice 1984, Lawrence et al. 1991). Allelopathic plants interfere with nearby plants by dispersing chemicals into the soil that may inhibit neighboring plant growth, nutrient uptake, or germination (Inderjit and Dakshini 1994, 1995, Inderjit 1996, Abhilasha et al. 2008). Allelochemicals are released into the environment via leachates and volatiles from live or dead plant roots and leaves (Jackson and Willemsen 1976, Rice 1984, Inderjit and Dakshini 1994, 1995, Inderjit 
1996). In most cases, the release of these chemicals results in more resources available to the allelopathic plant for uptake, which produces a net benefit. However, allelopathic plants can also be affected by their own chemicals (autoallelopathy), resulting in reduced growth (Kumari and Kohli 1987).

Because of observed depression of species richness and failed recruitment in heavily invaded areas, allelopathy is often invoked as a potential mechanism of invasive plant impact and success (Hierro and Callaway 2003, Prati and Bossdorf 2004, Abhilasha et al. 2008, Inderjit et al. 2008). However, these studies often focus on individual invaders and employ a variety of methods. This variation makes comparison among studies difficult and assessment of the toxicity of a particular invader relative to other species nearly impossible. We screened for the allelopathic potential of a suite of 10 non-native woodland invaders to assess the relative importance of allelopathy as a potential determinant of invasion success. By using standard methods across a suite of species, we can compare the relative strength of allelopathy and better predict which invasive species may exhibit allelopathy in the field.

Materials and Methods. The non-native invasive species all co-occurred within the young deciduous forests of the Hutcheson Memorial Forest Center (HMFC) in the Piedmont region of New Jersey, USA $\left(40^{\circ} 30^{\prime}\right.$ $\left.\mathrm{N}, 74^{\circ} 34^{\prime} \mathrm{W}\right)$. The research area was composed of 10 agricultural fields that had been abandoned 43-51 years prior. Successional processes in these fields have been described in detail from a series of permanent plots - the Buell-Small Succession Study (Pickett 1982, Myster and Pickett 1990, Meiners et al. 2002).

The species of focus were from a variety of plant life forms (trees, lianas, shrubs, and herbs) and represent all of the major forest invaders at the site. The species were: trees (Acer platanoides L. and Ailanthus altissima Miller (Swingle)), lianas (Celastrus orbiculatus Thunb. and Lonicera japonica Thunb.), shrubs (Elaeagnus angustifolia L., Ligustrum vulgare L., Rosa multiflora Thunb., and Rubus phoenocolasius Maxim), and herbs (Alliaria petiolata (Bieb.) Cavara \& Grande and Microstegium vimineum (Trin.) A. Camus). These species are all natives of Eurasia and found in disturbed woods, roadsides, and old fields throughout the northeastern United States (Gleason and Cronquist 1991, Rhoads and Block 2000). The species are also a concern to conservationists as they are able to occupy large areas within many plant communities. All of these species are considered invasive and many have been shown to have direct negative impacts on native communities (Fike and Niering 1999, Martin 1999, Hunter and Mattice 2002, Yurkonis et al. 2005, Morrison et al. 2007, Gómez-Aparicio and Canham 2008).

LABORATORy Bioassays. The effect of potentially allelopathic plants is often tested through bioassays, typically by testing the effects of plant tissue extracts on the germination of a target species. However, there are difficulties in relating laboratory bioassays to allelopathic interactions in the field related to slow release, low concentrations, or degradation of the allelopathic agent (Gibson 2002). In spite of these limitations, laboratory bioassays are useful for screening allelopathic potential, from which species can be selected for more detailed field studies to verify allelopathy. We employed a simple germination bioassay to survey the invasive plant species of HMFC for allelopathic potential.

Species were tested with laboratory bioassays following the methods of Butcko and Jensen (2002). For each species, leaves from at least 20 plants were collected from HMFC and dried at $60{ }^{\circ} \mathrm{C}$ for two days. Leaf tissue was used as it can disperse a greater distance than material from roots and often contains allelochemicals (Butcko and Jensen 2002). Extracts were made from $12.5 \mathrm{~g}$ of dried leaf tissue in $500 \mathrm{ml}$ of deionized water (Butcko and Jensen 2002). This ratio of biomass to water generates plant extracts that affect germination of target species and allows for differentiation among allelopathic species (Butcko and Jensen 2002, Pisula and Meiners 2010). Leaves were not ground as doing so results in the release of enzymes, salts, amino acids, and other compounds that may not be released under natural circumstances (Chou and Muller 1972, Inderjit and Dakshini 1995). The mixture was placed on a magnetic stirrer for 24 hours at room temperature and was strained through cheesecloth to remove particulate plant material. Dilutions of each extract, ranging from $0 \%$ to $100 \%$ in $10 \%$ increments, were made. Filter paper was placed in $90 \mathrm{~mm}$ Petri plates with 20 
Table 1. Effects of species identity (categorical variable) and extract concentration (continuous variable) on target species germination. Overall ANCOVA $F_{19,530}=43.16 ; P<0.0001 ; R^{2}=0.61$. Bolding indicates a significant $P$-value.

\begin{tabular}{lrrrr}
\hline \multicolumn{1}{c}{ Factor } & df & \multicolumn{1}{c}{ MS } & \multicolumn{1}{c}{$F$} & \multicolumn{1}{c}{$P$} \\
\hline Species & 9 & 78.52 & 1.01 & 0.4281 \\
Concentration & 1 & 30333.68 & $391.39<\mathbf{0 . 0 0 0 1}$ \\
$\begin{array}{l}\text { Species } \times \\
\quad \text { concentration }\end{array}$ & 9 & 1422.51 & $18.35<\mathbf{0 . 0 0 0 1}$ \\
\begin{tabular}{l} 
Error \\
\hline
\end{tabular} & 530 & 77.50 & & \\
\hline
\end{tabular}

seeds of the target species. We used radish (Raphanus sativus L. 'Early Scarlet Globe'; Bay Farm Services, Inc., Bay City, MI) as the target species in all trials. We used this species to indicate allelopathic potential because it germinates quickly, is commonly used in allelopathic studies, is sensitive to allelopathic inhibition, and detects differences among species' extracts (Butcko and Jensen 2002, Pisula and Meiners 2010).

Five trials were run at each dilution for each species tested. Four $\mathrm{ml}$ of extract was added to each plate and incubated at $25^{\circ} \mathrm{C}$ for a $12 / 12 \mathrm{~h}$ light/dark cycle. Petri plates were placed in bags to retain moisture. The plates were removed after four days and germinated seeds were counted. An analysis of covariance (ANCOVA) was used to measure the overall effect of plant extract concentration and species identity on germination (SAS 9.1; SAS Institute Inc., Cary, NC). Individual linear regressions of percentage germination as a function of extract concentration were conducted for each species. Coefficients $(\beta$ values) from these regressions were used to compare the relative strength of plant extracts on seed germination. We used $t$-tests to identify the threshold at which effects appeared relative to the control (SAS 9.1 SAS Institute Inc., Cary, NC). Due to limited replication at each concentration for threshold determination we chose to focus on regression $\beta$ values as a means of comparing species.

Results. Inhibition of germination in target seeds was influenced by the concentration of extract and the interaction of concentration of extract and species (Table 1, Fig. 1). However, species identity by itself was not significant in the ANCOVA. Regression analyses of individual species showed marked variation (Table 2). Plant extracts reduced target seed germination $(P<0.05)$ for all but one species (Elaeagnus angustifolia). Ailanthus altissima extracts had the greatest inhibitory effect (based on beta values) out of all 10 species while extracts from Acer platanoides, the other tree species, had small effects on germination. For the two lianas, Celastrus orbiculatus inhibited target seeds $(\beta=-0.28)$, more than Lonicera japonica $(\beta=-0.06$; Table 2$)$. Shrub extracts from Ligustrum vulgare, Rosa multiflora and Rubus phoenocolasius had uniformly small inhibitory effects on seed germination, even at higher concentrations. Extracts of the fourth shrub species, E. angustifolia, had no significant effect on target seed germination. Extracts of the herbaceous invaders Alliaria petiolata and Microstegium vimineum had large inhibitory effects on target species germination, only exceeded by the tree $A$. altissima. Threshold concentrations varied from $40 \%$ to $80 \%$ of full extract concentration and did not correspond to the rankings determined through regression analyses.

Table 2. Regression coefficients $(\beta \pm$ standard error) of the relationship between plant extract concentration and percent germination to quantify the strength of allelopathy for each invasive species. Threshold concentration refers to the lowest concentration at which germination was significantly decreased compared to the control using a $t$-test. Ranking is based on beta values: a ranking of 10 is the most toxic and 1 is the least toxic species. Bolding indicates a significant $P$-value.

\begin{tabular}{lccccccc}
\hline \multicolumn{1}{c}{ Species } & Rank & $\begin{array}{c}\text { Threshold } \\
\text { concentration }(\%)\end{array}$ & $\beta$ & $\begin{array}{c}\text { Standard } \\
\text { error }\end{array}$ & \multicolumn{1}{c}{$F_{1,53}$} & $R^{2}$ & $P$ \\
\hline Ailanthus altissima & 10 & 60 & -0.55 & 0.05 & 121.18 & 0.70 & $<\mathbf{0 . 0 0 0 1}$ \\
Microstegium vimineum & 9 & 70 & -0.38 & 0.04 & 72.66 & 0.58 & $<\mathbf{0 . 0 0 0 1}$ \\
Alliaria petiolata & 8 & 40 & -0.37 & 0.05 & 62.44 & 0.54 & $<\mathbf{0 . 0 0 0 1}$ \\
Celastrus orbiculatus & 7 & 70 & -0.28 & 0.04 & 50.42 & 0.49 & $<\mathbf{0 . 0 0 0 1}$ \\
Ligustrum vulgare & 6 & 60 & -0.19 & 0.04 & 22.05 & 0.30 & $\mathbf{0 . 0 0 0 1}$ \\
Rosa multiflora & 5 & 50 & -0.18 & 0.03 & 37.72 & 0.46 & $<\mathbf{0 . 0 0 0 1}$ \\
Rubus phoenocolasius & 4 & 70 & -0.16 & 0.03 & 21.98 & 0.29 & $<\mathbf{0 . 0 0 0 1}$ \\
Acer platanoides & 3 & 80 & -0.14 & 0.03 & 25.38 & 0.32 & $<\mathbf{0 . 0 0 0 1}$ \\
Lonicera japonica & 2 & 70 & -0.06 & 0.03 & 4.82 & 0.08 & $\mathbf{0 . 0 3 2 6}$ \\
Elaeagnus angustifolia & 1 & - & -0.03 & 0.02 & 1.53 & 0.03 & 0.2216 \\
\hline
\end{tabular}


Within plant life forms, shrubs and herbs had consistent levels of germination inhibition. Shrubs were all weakly allelopathic or had no effects while both herbaceous invaders had strong allelopathic potential. In contrast, liana and tree species had a mix of strong and weak effects on germination.

Discussion. In general, our results have confirmed the allelopathic potential previously found through varying methods for some of the species tested. In individual studies, bioassays of Ailanthus altissima (Lawrence et al. 1991, Gómez-Aparicio and Canham 2008) and Alliaria petiolata (Hanson and McCarthy 1998, Prati and Bossdorf 2004, Stinson et al. 2006, Cipollini and McClain 2008) revealed that they exhibited allelopathy in the lab or field. While these studies documented the potential of allelopathy for individual species, our study allows for direct comparison of species allelopathic potential as the same methods were employed for all species in a controlled setting. Ranking a large number of species based on allelopathic potential is a need for invasion centered studies, as predicting which species will be allelopathic in the field has been difficult to judge in the past. As more species are tested, the range of allelopathic potential will be refined and it will become easier to assess whether a plant is likely to exhibit strong allelopathic properties.

Our laboratory bioassays confirmed the presence of some allelopathic capability for all but one of the invasive specie's extract tested (Elaeagnus angustifolia). However, the response to plant extract concentration was not consistent within all life forms. The tree species, Ailanthus altissima, was the most inhibitory overall while the other invasive tree, Acer platanoides, reduced germination much less. Similarly, the two lianas differed in their allelopathic potential with Celastrus orbiculatus having a much greater effect on seed germination than Lonicera japonica. In contrast to these life forms, extracts of herbaceous and shrub species were largely consistent in their effects on target species germination. Herbaceous species consistently and strongly inhibited germination, whereas shrubs had a uniformly small effect (or no effect) on the germination of target seeds. Though based on a few species, this variation within life forms suggests limited utility of plant life form in predicting the presence of allelopathy.
Allelopathy is considered to be a competitive plant strategy as it allows for greater acquisition of resources (Grime 2001). For this reason, allelopathy may be more important in certain species rather than vary consistently across life forms. The invasive herbs Alliaria petiolata and Microstegium vimineum spread rapidly in forest understories in a variety of light conditions (Morrison et al. 2007) and appear to be strong competitors relative to many native understory herbs (Carlson and Gorchov 2004, Stinson et al. 2006, Morrison et al. 2007, Oswalt et al. 2007, but see Meekins and McCarthy 1999). Likewise, allelopathy may enhance the competitive success of the weedy and shade intolerant tree, Ailanthus altissima, which often regenerates in large canopy openings where competition may be intense. In contrast, the shade tolerance of Acer platanoides (Martin 1999), a stress tolerant strategy in Grime's C-S-R scheme (Grime 2001), would minimize the importance of allelopathy for the regeneration of this species. However, the allelopathic potential of shrubs does not appear to follow the expectations of Grime's plant strategies as the allelopathic potential of shrubs was uniformly low. The aggressive nature of these shrubs in abandoned agricultural land, particularly Rosa multiflora and Elaeagnus angustifolia, would suggest that they employ a competitive plant strategy and might have been expected to be strongly allelopathic.

If allelopathy is a broad mechanism contributing to species invasibility, we would expect native species on average to be less toxic than non-native species within the same community. However, the range of allelopathic potential for the invasive species tested here is similar to that documented for some native species from the same site. For example, native goldenrod (Solidago) species are often linked with allelopathy (Abhilasha et al. 2008, Pisula and Meiners 2010). Using the same method as this study, three out of six goldenrod species had beta values that were within the range found in this survey of non-natives (Pisula and Meiners 2010). The remaining goldenrod species were more toxic than any of the invasive species tested ( $\beta$ values ranging from -0.59 to -0.74 , Pisula and Meiners 2010). These results are important as goldenrods are considered invasive in Europe (Weber 2001, Abhilasha et al. 2008) and allelopathy has been invoked to explain their 


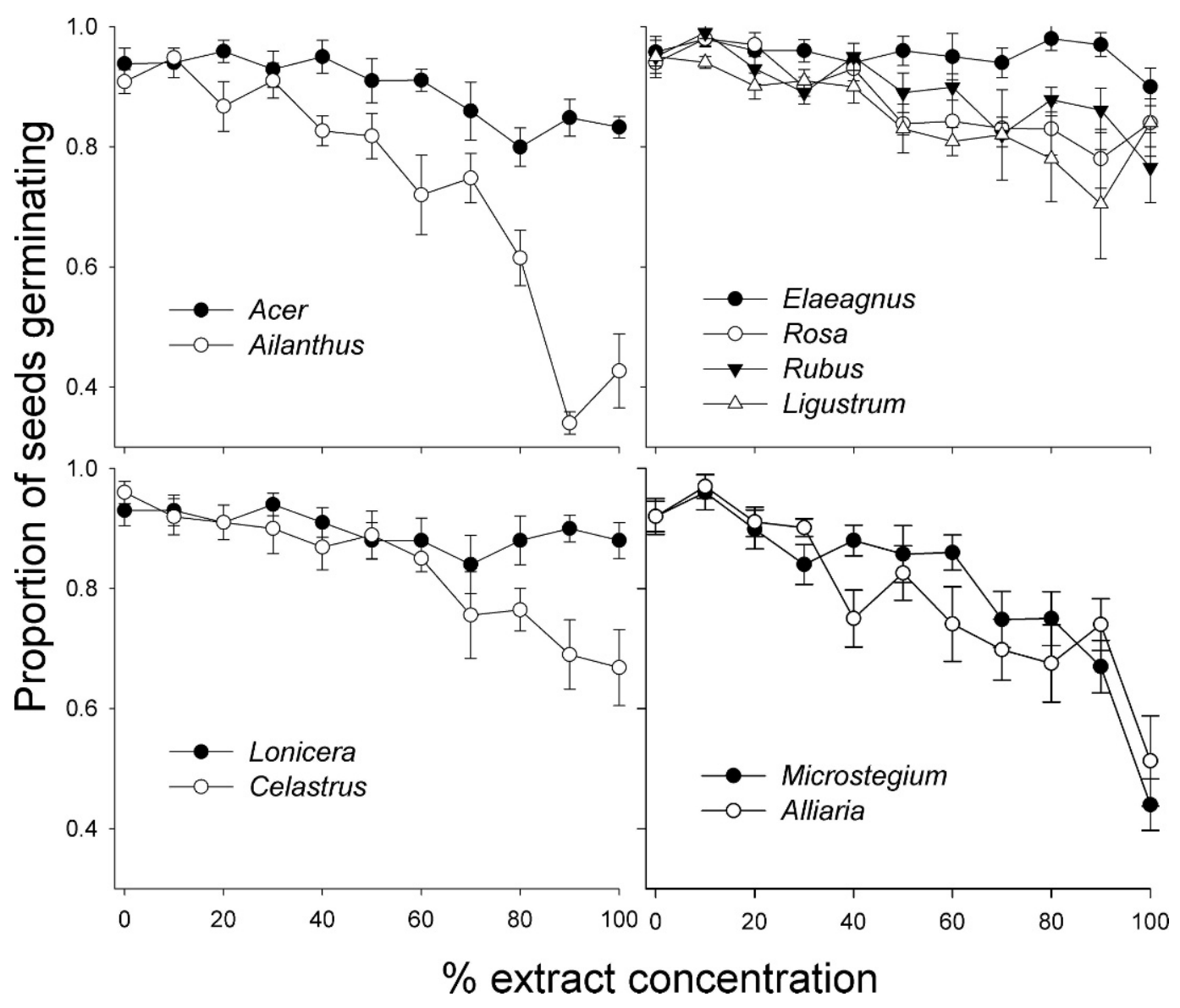

FIG. 1. Response of radish to plant extracts from 10 co-occurring invasive species. Data plotted are mean and standard error of the proportion germinated at extract concentrations ranging from $0-100 \%$. $N=$ 5 for each species at each concentration.

success in displacing native European flora. While allelopathy can clearly be important in some non-native plant invasions, it also appears to be a common component of native plant strategies at this site.

Moreover, the evolutionary experience of resident plants to the chemicals produced by invasive species may also be important in determining responses to allelopathy (Abhilasha et al. 2008, Thorpe et al. 2009). The novel weapons hypothesis suggests that native species that lack evolutionary exposure to a nonnative plant's allelochemicals should be more affected than plants from the native range of the invader (Callaway et al. 2008, Thorpe et al. 2009). While this effect may be important in invaded systems, we did not use both native and non-native target species and therefore cannot address the novel weapons hypothesis.
The role of evolutionary exposure in determining allelopathic responses needs to be assessed in a broader range of species.

The bioassay data presented here represent a preliminary screening of invasive species for their allelopathic potential only. From these data, species with sufficiently large inhibitory effects on germination may be selected for more detailed analyses in the field or in the laboratory. Allelochemicals in the field are likely released at different rates and may be lost from the soil through degradation, leaching, or binding with other chemical compounds (Inderjit and Dakshini 1995, Gibson 2002, Pisula and Meiners 2010). The balance between release and loss will determine the concentration, and therefore the efficacy, of allelochemicals within plant communities. Determining the persistence and concentration 
of allelochemicals is an important, but rarely done step as the identity of active chemicals is not always known. Of the species tested here, only Alliaria petiolata has been sufficiently characterized (Barto and Cipollini 2009). Alternatives to detailed chemical analyses of putative allelopathic invaders include germination bioassays of co-occurring native species and the use of activated carbon or plant leachate additions in greenhouse and field experiments (Cipollini and McClain 2008, Gómez-Aparicio and Canham 2008). All of these approaches can help to evaluate importance of allelopathy in species invasion.

Conclusions. While allelopathy has been implicated in many invasion case studies, we still lack a clear understanding of its prevalence and importance in plant communities. The majority of species we tested showed some allelopathic potential. However, there was no clear pattern among life forms that would allow a prediction of which invasive species should be expected to exhibit allelopathy. We encourage the use of this or similar methods to compare species' relative allelopathic potential to screen and prioritize invasive species for further study. Four species, Ailanthus altissima, Alliaria petiolata, Celastrus orbiculatus, and Microstegium vimineum all exhibited strong germination inhibition and warrant additional study in the field. A broad suite of native species should also be tested to determine the importance of allelopathy in structuring native communities and to develop predictions of which species have a strong potential for allelopathy. Comparative studies provide a critical tool that will allow us to assess the importance of allelopathy and its effects on population and community dynamics.

\section{Literature Cited}

Abhilasha, D., N. Quintana, J. Vivanco, And J. Joshi. 2008. Do allelopathic compounds in invasive Solidago canadensis s.1. restrain the native European flora? J. Ecol. 96: 993-1001.

Barto, E. K. And D. Cipollini. 2009. Half-lives and field soil concentrations of Alliaria petiolata secondary metabolites. Chemosphere 76: 71-75.

Butcko, V. M. And R. J. Jensen. 2002. Evidence of tissue-specific allelopathic activity in Euthamia graminifolia and Solidago canadensis (Asteraceae). Am. Midl. Nat. 148: 253-262.

Byers, J. E., S. Reichard, J. M. Randall, I. M. Parker, C. S. Smith, W. M. Lonsdale, I. A. E. Atkinson, T. R. Seastedt, M. Williamson, E.
Chornesky, And D. Hayes. 2002. Directing research to reduce the impacts of nonindigenous species. Conserv. Biol. 16: 630-640.

Callaway, R. M., D. Cipollini, K. Barto, G. C. Thelen, S. G. Hallett, D. Prati, K. Stinson, And J. KLironomos. 2008. Novel weapons: Invasive plant suppresses fungal mutualists in America but not in its native Europe. Ecology 89: 1043-1055.

Carlson, A. M. and D. L. Gorchov. 2004. Effects of herbicide on the invasive biennial Alliaria petiolata (garlic mustard) and initial responses of native plants in a southwestern Ohio forest. Restor. Ecol. 12: 559-567.

Chou, C. H. And C. H. Muller. 1972. Allelopathic mechanisms of Arctostaphylos glandulosa var. zacaensis. Am. Midl. Nat. 88: 324-347.

Cipollini, K. A. and G. Y. McClain. 2008. Separating above- and belowground effects of Alliaria petiolata and Lonicera maackii on the performance of Impatiens capensis. Am. Midl. Nat. 160: 117-128.

Crawley, M. J. 1987. What makes a community invasible? p. 429-454. In A. J. Gray, M. J. Crawley, and P. J. Edwards [eds.], Colonization, Succession, and Stability. Blackwell Scientific Publications, Boston, MA.

Ehrenfeld, J., G. P. Kourtev, and W. Huang. 2001. Changes in soil functions following invasions of exotic understory plants in deciduous forests. Ecol. Appl. 11: 1287-1300.

Fike, J. AND W. A. Niering. 1999. Four decades of old field vegetation development and the role of Celastrus orbiculatus in the northeastern United States. J. Veg. Sci. 10: 483-492.

Gibson, D. J. 2002. Methods in Comparative Plant Population Ecology. Oxford University Press, Oxford, New York, NY. 344 p.

Gleason, H. A. And A. Cronguist. 1991. Manual of Vascular Plants of Northeastern United States and Adjacent Canada. Second Edition. The New York Botanical Garden, New York, NY. 910 p.

Gómez-Aparicio, L. AND C. D. CANHam. 2008. Neighborhood analyses of the allelopathic effects of the invasive tree Ailanthus altissima in temperate forests. J. Ecol. 96: 447-458.

Grime, J. P. 2001. Plant Strategies, Vegetation Processes, and Ecosystem Properties. Second Edition. John Wiley \& Sons Ltd, Chichester, West Sussex, England. 417 p.

Hanson, S. L. and B. C. McCarthy. 1998. An assessment of the allelopathic potential of the invasive weed Alliaria petiolata (Brassicaceae). Castanea 63: 68-73.

Hierro, J. L. and R. M. Callaway. 2003. Allelopathy and exotic plant invasion. Plant Soil 256: 29-39.

Hunter, J. C. And J. A. Mattice. 2002. The spread of woody exotics into the forests of a northeastern landscape, 1938-1999. J. Torrey Bot. Soc. 129: $220-227$.

Huston, M. A. 2004. Management strategies for plant invasions: manipulating productivity, disturbance, and competition. Divers. Distrib. 10: $167-178$.

InDERJIT AND K. M. M. DAKSHINI. 1994. Allelopathic effects of Pluchea lanceolata on characteristics of 
four soils and growth of mustard and tomato. Am. J. Bot. 81: 799-804.

INDERJIT AND K. M. M. DAKShINI. 1995. On laboratory bioassays in allelopathy. Bot. Rev. 61: 28-44.

INDERJIT. 1996. Plant phenolics in allelopathy. Bot. Rev. 62: 186-202.

Inderjit. 2008, , T. R. Seastedt, R. M. Callaway, J. L. Pollock, and J. Kaur. 2008. Allelopathy and plant invasions: traditional, congeneric, and bio-geographical approaches. Biol. Invasions 10: 875-890.

JACKSON, J. R. AND R. W. WILlEMSEN. 1976. Allelopathy in the first stages of secondary succession on the piedmont of New Jersey. Am. J. Bot. 63: 1015-1023.

Kumari, A. And R. K. Kohli. 1987. Autotoxicity of ragweed parthenium (Parthenium hysterophorus). Weed Sci. 35: 629-632.

Lawrence, J. G., A. Colwell, and O. J. Sexton. 1991. The ecological impact of allelopathy in Ailanthus altissima (Simaroubaceae). Am. J. Bot. 78: 948-958.

Mack, R. N., D. Simberloff, W. M. Lonsdale, H. Evans, M. Clout, and F. A. Bazzaz. 2000. Biotic invasions: causes, epidemiology, global consequences, and control. Ecol. Appl. 10: 689-710.

Martin, P. H. 1999. Norway maple (Acer platanoides) invasion of a natural forest stand: Understory consequence and regeneration pattern. Biol. Invasions 1: 215-222.

Meekins, J. F. And B. C. MCCarthy. 1999. Competitive ability of Alliaria petiolata (Garlic mustard, Brassicaceae), an invasive nonindigenous forest herb. Int. J. Plant Sci. 160: 743-752.

Meiners, S. J., S. T. A. Pickett, And M. L. Cadenasso. 2002. Exotic plant invasions over 40 years of old field succession: community patterns and associations. Ecography 25: 215223.

Morrison, J. A., H. A. Lubchansky, K. E. Mauck, K. McCartney, and B. Dunn. 2007. Ecological comparison of two co-invasive species in eastern deciduous forests: Alliaria petiolata and Microstegium vimineum. J. Torrey Bot. Soc. 134: 1-17.

Myster, R. W. and S. T. A. Pickett. 1990. Initial conditions, history, and successional pathways in ten contrasting old fields. Am. Midl. Nat. 124: 231-238.

Newman, E. I. 1983. Interactions between plants. In O. L. Lang, P. S. Nobel, C. B. Osmond, and H. Ziegler [eds.], Physiological Plant Ecology III:
Responses to the Chemical and Biological Environment. Springer-Verlag, Berlin, FRG.

Oswalt, C. M., S. N. Oswalt, and W. K. Clatterbuck. 2007. Effects of Microstegium vimineum (Trin.) A. Camus on native woody species density and diversity in a productive mixed-hardwood forest in Tennessee. Forest Ecol. Manage. 242: 727-732.

Pickett, S. T. A. 1982. Population patterns through twenty years of oldfield succession. Vegetatio 49 : 45-59.

Pisula, N. L. and S. J. Meiners. 2010. Allelopathic effects of goldenrod species on turnover in successional communities. Am. Midl. Nat. 163: $161-172$.

Prati, D. And O. Bossdorf. 2004. Allelopathic inhibition of germination by Alliaria petiolata (Brassicaceae). Am. J. Bot. 91: 285-288.

Reichard, S. H. AND C. W. Hamilton. 1997. Predicting invasions of woody plants introduced into North America. Conserv. Biol. 11: 193-203.

REJMÁNEK, M. 1999. Invasive plant species and invasible ecosystems, p. 79-102. In O. Y. Sandlund [ed.], Invasive Species and Biodiversity Management. Kluwer Academic Publishers, Dordrecht, Netherlands.

ReJMÁNeK, M. AND D. M. Richardson. 1995. What attributes make some plant species more invasive? Ecology 77: 1655-1661.

Rhoads, A. F. And T. A. Block. 2000. The Plants of Pennsylvania. University of Pennsylvania Press, Philadelphia, PA. 1061 p.

Rice, E. L. 1984. Allelopathy. Second Edition. Academic Press, New York, NY. 422 p.

Stinson, K. A., S. A. Campbell, J. R. Powell, B. E. Wolfe, R. M. Callaway, G. C. Thelen, S. G. Hallett, D. Prati, and J. N. Klironomos. 2006. Invasive plant suppresses the growth of native tree seedlings by disrupting belowground mutualisms. PLoS Biology 4: 727-731.

Thorpe, A. S., G. C. Thelen, A. Diaconu, and R. M. Callaway. 2009. Root exudate is allelopathic in invaded community but not in native community: field evidence for the novel weapons hypothesis. J. Ecol. 97: 641-645.

Weber, E. 2001. Current and potential ranges of three exotic goldenrods (Solidago) in Europe. Conserv. Biol. 15: 122-128.

Williamson, M. 1996. Biological Invasions. Chapman \& Hall, London, UK. 244 p.

Yurkonis, K. A., S. J. Meiners, and B. WaChHOLDER. 2005. Invasion impacts diversity through altered community dynamics. J. Ecol. 93: 1053-1061. 